\title{
EVOLUTION OF ANEMIA IN CHRONIC KIDNEY DISEASE PATIENTS
}

\section{EVOLUÇÃO DA ANEMIA EM PACIENTES COM DOENÇA RENAL CRÔNICA}

\author{
Marielly Pachtman ${ }^{1}$, Camila Orsi ${ }^{1}$, Isabella Schroeder Abreu ${ }^{2}$, Welligton Luciano \\ Braguini $^{3}$ \\ ${ }^{1}$ Departamento de Farmácia da Universidade Estadual do Centro Oeste, Guarapuava, \\ Paraná, Brazil. \\ ${ }^{2}$ Departamento de Enfermagem da Universidade Estadual do Centro Oeste, Guarapuava, \\ Paraná, Brazil. \\ ${ }^{3}$ Departamento de Ciências Biológicas da Universidade Estadual do Centro Oeste, \\ Guarapuava, Paraná, Brasil. E-mail: wbraguini@yahoo.com.br \\ Data de recebimento: $17 / 12 / 2013$ \\ Data da aprovação: 15/03/2014
}

\begin{abstract}
Variations in hematocrit and hemoglobin values are constantly checked in patients with chronic kidney disease (CKD) on dialysis in order to monitor the anemia. Anemia and iron deficiency are the most frequent and severe nutritional deficiencies, acting as a cause of morbidity in individuals carrying CKD. The work aimed to monitor the evolution of laboratory parameters of chronic renal patients on dialysis of a clinic in the state of Paraná, Brazil, for twelve months, correlating them with the drug therapy (iron injection and EPO). This is a cross-sectional investigation of quantitative character, whose data were collected from the results of laboratory tests of 108 adult patients. The data showed that at the beginning of the study $86.1 \%$ of patients were anemic; the number of patients with serum iron less than $50 \mu \mathrm{g} / \mathrm{mL}$ increased $27 \%$, and the number of patients with TSAT $<20 \%$ increased $129 \%$. The results emphasize the importance of careful evaluation of laboratory values by the health professionals, especially the nephrology clinical team, who deal with patients with CKD through the identification and correction of clinical and laboratory factors that alter the clinical picture of the patient.
\end{abstract}

Keywords: Chronic renal disease. Anemia. Dialysis.

\section{RESUMO}

As variações nos valores de hematócrito e hemoglobina são constantemente avaliadas em pacientes com doença renal crônica (DRC) em diálise para controlar a anemia. A anemia e deficiência de ferro são mais frequentes e graves deficiências nutricionais, atuando como causa de morbidade em indivíduos portadores de DRC. O trabalho teve como objetivo acompanhar a evolução dos parâmetros laboratoriais de pacientes renais crônicos em diálise de uma clínica no estado do Paraná por doze meses, correlacionandoos com a terapia medicamentosa (injeção de ferro e EPO). Trata-se de uma pesquisa transversal de caráter quantitativo, cujos dados foram coletados dos resultados dos testes laboratoriais de 108 pacientes adultos. Os dados mostraram que, no início do estudo, $86,1 \%$ dos pacientes eram anêmicos; o número de pacientes com ferro sérico inferior a $50 \mu \mathrm{g} / \mathrm{mL}$ aumentou $27 \%$, e o número de pacientes com TSAT $<20 \%$ aumentou $129 \%$. Os resultados ressaltam a importância de cuidadosa avaliação dos valores de laboratório 
pelos profissionais de saúde, especialmente a equipa clínica da área de Nefrologia, que lidam com pacientes com DRC, através da identificação e correção de fatores clínicos e laboratoriais que alteram o quadro clínico do paciente.

Palavras-chave: Doença renal crônica. Anemia. Diálise.

\section{INTRODUCTION}

The prevalence of hemodialysis in Brazil has increased in recent years from 24.000 in 1994 to more than 54.500 patients in 2002 (ROMÃOJÚNIOR, 2004), and in 2009 it was estimated an approximate number of 77.589 dialysis patients, and a gross mortality rate of 17.1 (SESSO et al., 2010). Currently it is estimated that there is 91.314 patients performing dialysis in Brazil, being $84.5 \%$ from SUS (Sistema Único de Saúde) and 15.1\% from others agreements. These $66.9 \%$ have 19 to 64 year old and $35.1 \%$ have hypertension as underlying disease (SOCIEDADE BRASILEIRA DE NEFROLOGIA, 2011). However, a recent study indicates that about 2.9 million Brazilians can submit one third or less of the glomerular filtration rate of normal individuals (FERNANDES; BASTOS, 2010).

With the increase of renal function loss on clinical manifestations, anemia is the often complication observed whose prevalence and intensity relates to the stage of renal disease and deficiency of erythropoietin (EPO) (ESCHBACH; ADAMSON, 1985) (CORESH et al., 2001). Other situations may contribute to the advent of anemia, such as: iron deficiency, blood loss, the hyperparathyroidism and inflammation (BRITTENHAM, 1995).

Deficiency of iron $(\mathrm{Fe})$ is a severe nutritional deficiency that has high morbidity in individuals carrying chronic kidney disease (CKD) (WHO, 2001). Therefore, the patient's level of iron with CKD requires constant evaluation. Supplementation with iron ensures an adequate response to EPO in patients with $\mathrm{CKD}$, since the iron bone marrow erythroid hypoplasia demands often exceeded amount of iron available for erythropoiesis (measured by percentage of transferrin saturation - TSAT) as well as stocks of iron (measured by serum ferritin). In most hemodialysis patients intravenous application of iron is necessary to achieve adequate stocks of iron (K/DOQI, 2006).

Most patients with $\mathrm{CKD}$ have anemia, normocytic and normochromic (ESCHBACH;
ADAMSON, 1985). Anemia is associated with several physiological disorders in CKD, including decrease of oxygen use and release into the body (HORINA et al., 1993; MAYER et al., 1988; TEEHAN et al., 1989; ROBERTSON et al., 1990; BRAUMANN et al., 1991), increased cardiac output, cardiac area increased, ventricular hypertrophy, angina, congestive heart failure (HARNETT et al., 1995) (WIZEMANN; SCHAFER; KRAMER, 1993), reduction of mental acuity and cognition (WOLCOTT et al., 1989), alteration of menstrual cycles (RAMIREZ et al., 1994) and impairment of immune response (GAFTER et al., 1994). In addition, anemia can retard growth of pediatric patients (SCIGALLA et al., 1989). These abnormalities reduce the quality of life (EVANS; RADER; MANNINEN, 1990) and opportunities for rehabilitation in patients that survived CKD (LOWRIE et al., 1994). Monitoring the evolution of patients enables creating a therapy according to the physiological necessity of the organism, since clinical-laboratory parameters can change significantly over time.

Chronic renal disease is currently a public health problem worldwide, and that has been an increase in its incidence mainly due to the greater life expectancy, and an increase in the prevalence of diabetes mellitus and hypertension in population. The health expenditures in dialysis and renal transplant in Brazil exceed 1.8 billion a year (ROMÃO-JÚNIOR, 2004). The research for new therapeutic strategies is a constant attempt to improve the quality of life of patients. Thus, the aim of this paper is to describe and assess the evolution of chronic renal patients on hemodialysis with regard to the development of anemia, their treatment during the period of one year and correlate it with laboratory parameters.

\section{Materials and methods}

This is a cross-sectional study of quantitative character, whose data were collected through the records of the results of laboratory tests and monthly prescriptions of EPO and iron of 108 adult dialysis 
patients from the city of Guarapuava, in the state of Paraná, Brazil. The following criteria were used to include patients in this study: 1) patient must have CKD; 2) be in dialysis for more than six months; 3 ) not have suffered kidney transplant in the past; 4) be over 18 years.

All adopted procedures to provide information have been assessed and approved by the Ethics Committee of Midwest State University UNICENTRO, through the opinion letter 121/2009.

The laboratory data presented in this study were collected from January to December 2010. All laboratory examinations for this period were carried out by a laboratory located in Santa Tereza Hospital, in the city of Guarapuava.

The patients received exogenous EPO and $100 \mathrm{mg}$ of iron hydroxide saccharate (Fe III), up to 4 times a week. The doctors of the hemodialysis clinic adjusted the doses of EPO and Fe according to the patient's anemia and to prevent iron overload.

Data from the hematocrit $(\mathrm{Ht})$ and hemoglobin $(\mathrm{Hb})$ were obtained every 30 days, and dosages of serum iron and transferrin were obtained every 90 days. The index of transferrin saturation (TSAT) was also obtained through determination of iron and iron-binding.

The data were stored in a database and, at the end of the collection, the data were analyzed through descriptive statistics. The laboratory findings were presented through average \pm standard deviation and times a week, in the period of the study. The EPO was administered to all patients in the study. The EPO and iron administration was performed to patients whose results of the laboratory parameters of every 30 days of hematocrit and hemoglobin reached adjacent values to dialysis patients with CKD. The EPO administration was suspended as medical criteria through the analysis of hemoglobin and hematocrit.

A total of 60 men $(89.5 \%$ of men) and 33 women (80.4\% of women) presented anemia (Table 1 ), according to the criteria of Clinical Practice Guidelines and Clinical Practice Recommendations for Anemia in Chronic Kidney Disease (K/DOQI, 2006) which considers anemic individuals those with $\mathrm{Ht}$ less than $33 \%$ for woman and less than $37 \%$ for man.

Table 1 - Percentage of anemic and non-anemic in relation to patient hematocrit values. Data obtained between January and December 2010 - Guarapuava, Paraná, Brazil

\begin{tabular}{c|c|c}
\hline & \multicolumn{2}{|c}{ Patients } \\
\hline Parameter & Anemic & Non-anemic \\
\hline Hematocrit & $86.1 \%(\mathrm{n}=93)$ & $13.9 \%(\mathrm{n}=15)$ \\
\hline
\end{tabular}
Source: Pachtman et al. 2010.

The average hematocrit of all patients at the end of six months and at the end of one year was $31 \pm 4.5$ and $31 \pm 5$, respectively. The data of laboratory parameters of $\mathrm{Ht}$ and $\mathrm{Hb}$ of patients are listed in Table 2.

Table 2 - Laboratory parameters of hematocrit $(\mathrm{Ht})$ and hemoglobin $(\mathrm{Hb})$ concentration of 108 patients in 2010 . Data obtained between January and December 2010 - Guarapuava, Paraná, Brazil

\begin{tabular}{c|c|c|c}
\hline & \multicolumn{3}{|c}{ Patients } \\
\hline Variable & $\begin{array}{c}\text { Average ( } \pm \text { SD*) } \\
(\text { January }- \text { June) }\end{array}$ & $\begin{array}{c}\text { Average ( } \pm \text { SD) } \\
\text { (July }- \text { December) }\end{array}$ & P value* \\
\hline Hematocrit (Ht) (\%) & $31 \pm 4.5$ & $31 \pm 5$ & $>0.05$ \\
\hline Hemoglobin (Hb) (g/dL) & $10.3 \pm 1.3$ & $10.4 \pm 1.4$ & $>0.05$ \\
\hline
\end{tabular}

*SD: Standard deviation.

Source: Pachtman et al. 2010.

percentage using Graph Pad Prism ${ }^{\circledR} 5.01$ (2001) and Microsoft Excel ${ }^{\circledR}$ 2007. Statistical significance was established by ANOVA in $5 \%(\mathrm{p}<0.05)$.

\section{Results and discussion Prevalence of anemia}

The sampling was composed of 108 patients, being 67 men (62\%) and 41 women $(38 \%)$. A total of 49 patients (45.4\%) received $100 \mathrm{mg}$ of iron, 2 to 4
The iron administration during the period of the study gradually decreased, as demonstrated in Table 3. The iron administration aims to maintain adequate levels in a way that patients with CKD can achieve and maintain a $\mathrm{Ht}$ level of 33 to $37 \%$ (Hb 11 to $12 \mathrm{~g} /$ dL) along with treatment with EPO. 
Table 3 - Number of patients receiving intravenous iron administration and percentage of patient receiving iron for each 3 months. Data obtained between January and December 2010 - Guarapuava, Paraná, Brazil

\begin{tabular}{c|c|c}
\hline & \multicolumn{2}{|c}{ Number of patients } \\
\hline Jan-Mar & \# of patients receiving iron & \% of patients receiving iron \\
\hline Apr-Jun & 48 & 34.4 \\
\hline Jul-Sep & 35 & 32.4 \\
\hline Oct-Dec & 36 & 33.3 \\
\hline Average & 35 & 32.4 \\
\hline
\end{tabular}

Source: Pachtman et al. 2010.

Figure 1 shows a decrease in the number of patients with ferritin $>200 \mathrm{ng} / \mathrm{mL}$ and an increase in the number of patients with ferritin $<30 \mathrm{ng} / \mathrm{mL}$.

Figure 1 - Number of hemodialysis patients with ferritin values less than $30 \mathrm{ng} / \mathrm{mL}$, less than $100 \mathrm{ng} / \mathrm{mL}$ and greater than $200 \mathrm{ng} / \mathrm{mL}$ per quarter in 2010 . Data obtained between January and December 2010 - Guarapuava, Paraná, Brazil

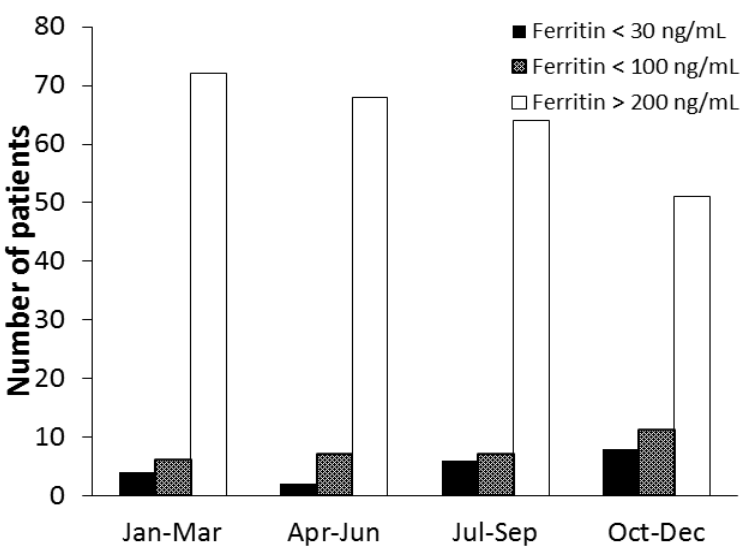

Source: Pachtman et al. 2010.

Figure 2 shows that during the year evaluated the number of patients with serum iron less than $50 \mu \mathrm{g} / \mathrm{mL}$ increased $27 \%$, and the number of patients with TSAT $<20 \%$ increased $129 \%$.
Figure 2 - Number of hemodialysis patients with serum iron $<50 \mu \mathrm{g} / \mathrm{dL}$ and TSAT $<20 \%$. Data obtained between January and December 2010 Guarapuava, Paraná, Brazil

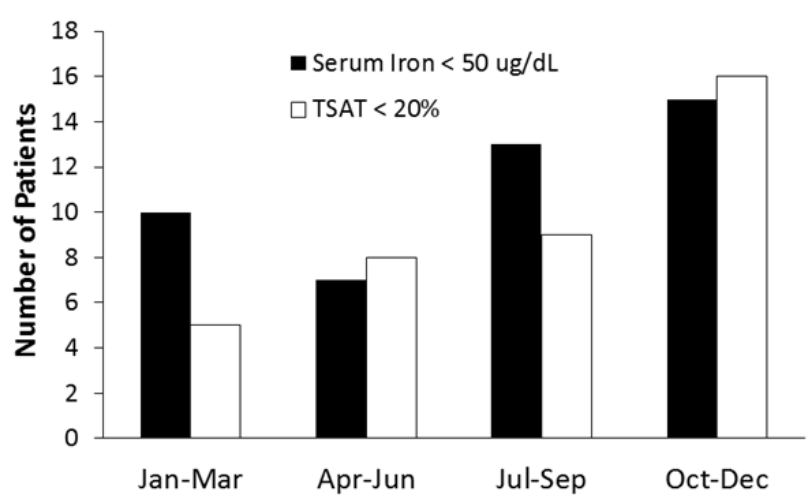

Source: Pachtman et al. 2010.

Table 4 shows the number of individuals with absolute and relative deficiency of iron according to the following criteria: ferritin $<100 \mu \mathrm{g} / \mathrm{L}$ and TSAT $<20 \%$ for absolute iron deficiency, and ferritin $<300 \mu \mathrm{g} / \mathrm{L}$ and $\mathrm{TSAT}<30 \%$ for relative iron deficiency.

Table 4 - Patients with absolute and relative deficiency of ferritin. Data obtained between January to December 2010 Guarapuava, Paraná, Brazil

\begin{tabular}{c|c|c|c|c}
\hline & \multicolumn{2}{|c|}{ Absolute deficiency } & \multicolumn{2}{c}{ Relative deficiency } \\
\hline & Ferritin<100mg/L & TSAT $<\mathbf{2 0} \%$ & Ferritin<300mg/L & TSAT<30\% \\
\hline Jan-Mar & 4 & 6 & 8 & 14 \\
\hline Apr-Jun & 9 & 5 & 21 & 13 \\
\hline Jul-Sep & 14 & 9 & 35 & 10 \\
\hline Oct-Dec & 19 & 16 & 42 & 24
\end{tabular}

Source: Pachtman et al. 2010. 
In the study, an increase of individuals with ferritin and TSAT deficiency was observed in each quarter. The deficiency is considered relative or functional when the patient presents ferritin values between 100 and $300 \mu \mathrm{gL}$ and transferrin saturation between $20 \%$ and $30 \%$. The administration of intravenous iron induces an improvement in hemoglobin level.

\section{Conclusion}

Changes in hematologic and biochemical variables of 108 patients were followed for a period of one year, and although the average values of hematocrit and hemoglobin of the patients remained similar in the first and second halves of the study, it was observed that the absolute and relative deficiency of iron increased, reflecting directly on the values of ferritin and TSAT. The intravenous administration of iron in quantities exceeding required for physiological phenomena promotes excessive production of cellular stress, but also progressively improves the ferric profile.

Evaluation of iron levels of the patients was carried out using ferritin and TSAT. The evolution of hematological parameters of patients observed in this study is similar to those described in the literature about nephrogenic anemia correction with intravenous iron therapy (TARNG; CHEN; HUANG, 1995; NATIONAL KIDNEY FOUNDATION, 1997; LUDAT et al., 2000; LIM et al., 1999; MIMIC-OKA et al., 2005). However, iron supplementation should be evaluated with caution due to possible side effects, particularly in high doses of intravenous iron (LIM et al., 1999; ROOYAKKERS et al., 2002; CAVDAR et al., 2003; MIMIC-OKA et al., 2005).

The worsening of CKD depends on interactions that involve several clinical factors, among others. Age, gender, diabetes, hypertension, proteinuria, anemia, obesity, metabolic complications, smoking and dyslipidemia are among the clinical factors, which together with genetic and environmental factors can aggravate the framework of CKD (BASTOS; KIRSZTAJN, 2011). Anemia is common in patients with CKD, and patients with lower values of hemoglobin have worse outcomes than those with higher values. Hemoglobin value $<13 \mathrm{~g} / \mathrm{dL}$ for adult men and $<12.0 \mathrm{~g} / \mathrm{dL}$ for women and men $>65$ years are the criteria of Brazilian guidelines for the assessment of these patients (RIBEIRO-ALVES; GORDAN, 2007). The reserves of iron evaluated in the study by ferritin were considered appropriate when over $100 \mu \mathrm{g} / \mathrm{L}$ and transferrin saturation greater than $20 \%$ in evaluated patients (BASTOS; KIRSZTAJN, 2011). However, absolute iron deficiency was explained in Table 4, where the number of patients with ferritin $<100 \mu \mathrm{g} / \mathrm{L}$ and TSAT $<20 \%$ went from 4 to 19 and 6 to 16, respectively, over the year of the survey.

The fact that some patients do not reach adequate levels of iron, ferritin and TSAT (Table 3 ), even with a high dose of EPO, can be due to infectious complications or bleeds. The criterion used by clinical staff, in these cases, is to keep the dose of EPO and re-evaluate the patient after the acute phase of complication.

Treatment with EPO increases the rate of erythropoiesis, and therefore the demand for iron, which results in difficulty to maintain optimal levels of iron in hemodialysis patients when coupled with the substantial blood loss. The use of intravenous iron treatment is more effective against anemia associated with CKD in hemodialysis patients. However, hypersensitivity reactions may occur in this type of treatment, which would not occur in the treatment with oral iron (ESCÓRCIO et al., 2010).

The findings obtained in this study emphasize the importance of a careful evaluation of laboratory values on the part of health professionals, especially nephrologists who often deal with patients with CKD. The potential benefits of careful and judicious evaluation include identifying and correcting factors that worsen the clinical picture of the patient, for example, correction of laboratory values by obtaining the best biochemical parameters.

\section{ACKNOWLEDGEMENTS}

To CLIRE - Kidney Disease Clinic Ltd. and staff by the collaboration in this study.

\section{We declare no conflict of interest.}




\section{REFERENCES}

BASTOS, M.; KIRSZTAJN, G. Doença renal crônica: importância do diagnóstico precoce, encaminhamento imediato e abordagem interdisciplinar estruturada para melhora do desfecho em pacientes ainda não submetidos à diálise. J Bras Nefrol, v.33, n.1, p.93-108, 2011.

BRAUMANN, K. M. et al. Improved physical performance after treatment of renal anemia with recombinant human erythropoietin. Nephron, v.58, p. 129-134, 1991.

BRITTENHAM, G. Disorders of iron metabolism - Iron deficiency and overload. In: HOFFMAN, R. Hematology Basic Principles. 2. ed. [S. 1.]: [s. n.], p.492-522, 1995.

CAVDAR, C. et al. The effects of intravenous iron treatment on oxidant stress and erythrocyte deformability in hemodialysis patients. Scand J Urol Nephrol, v.37, n. 1, p.77-82, 2003.

CORESH, J. et al. Prevalence of high blood pressure and elevated serumcreatinine level in United States: findings from the third National Health and Nutrition Examination Survey (1988-1994). Arch Intern Med, v.161, p.12071216, 2001

ESCHBACH, J. W.; ADAMSON, J. W. Anemia of endstage renal disease (ESRD). Kidney Int, v.28, p.1-5, 1985.

ESCÓRCIO, C. S. M. et al. Avaliação do tratamento da anemia em pacientes com insuficiência renal crônica, em hemodiálise, em uso de eritropoetina, ferro oral e endovenoso.

Rev Bras Análises Clínicas, v.42, p.87-90, 2010.

EVANS, R. W.; RADER, B.; MANNINEN, D. L. Cooperative Multicenter EPO Clinical Trial Group: The quality of life of hemodialysis recipients treated with recombinant human erythropoietin. JAMA,v. 263, p.825$830,1990$.

FERNANDES, N.; BASTOS, R. B. M. Diagnóstico da doença renal crônica a partir da filtração glomerular estimada: CKD-EPI ou MDRD [resumo]. Congresso Brasileiro de Nefrologia. [S. 1.]: [s. n.]. 2010. p.506.

GAFTER, U. et al. Anemia of uremia is associated with reduced in vitro cytokine secretion: Immunopotentiating activity of red blood cells. Kidney Int, v.45, p.224-231, 2004.

HARNETT, J. D. et al. Congestive heart failure in dialysis patients: Prevalence, incidence, prognosis and risk factors. Kidney Int, v.47, p.884-890, 1995

HORINA,J.Hetal.Increased red cell2,3-diphosphoglycerate levels in haemodialysis patients treated with erythropoietin. Nephrol Dial Transplant, v.8, p.1219-1222, 1993.

K/DOQI. National Kidney Foundation clinical practice guidelines and clinical practice recommendations for anemia in chronic kidney disease. Am J Kidney Dis, v.47, n. 5, S11-S145, 2006.
LIM, R. S. et al. Enhanced oxidative stress in hemodialysis patients receiving intravenous iron therapy. Nephrol Dial Transplant, v.14, p.2680-2687, 1999.

LOWRIE, E. G. et al. The relative contribution of measured variables to death risk among hemodialysis patients. In: FRIEDMAN, E. A. Death on Hemodialysis: Preventable or Inevitable? Boston: Kluwer Academic Publishers, 1994. p.121-141.

LUDAT, K. et al. Oxidation parameters in complete correction of renal anaemia. Clin Nephrol, v.53, n.S1, p.530-535, 2000 .

MAYER, G. et al. Working capacity is increased following recombinant human erythropoietin treatment. Kidney Int, v.34, p.525-528, 1988

MIMIC-OKA, J. et al. Evaluation of Oxidative Stress after Repeated Intravenous Iron Supplementation. Renal Failure, v.27, p.345-351, 2005.

NATIONAL KIDNEY FOUNDATION. Dialysis outcomes quality initiative. Clinical guide lines for the treatment of anemia of chronic renal failure. III iron support. Am J Kidney Dis, v.30, n.4, suppl.3, s192-s240, 1997.

RAMIREZ, G. et al. The effects of corticotropin and growth hormone releasing hormones on their respective secretory axes in chronic hemodialysis patients before and after correction of anemia with recombinant human erythropoietin. J Cllin Endocrinol Metab, v.78, p.63-69, 1994.

ROBERTSON, H. T. et al. Recombinant erythropoietin improves exercise capacity in anemic hemodialysis patients. Am J Kidney Dis, v.15, p.325-332, 1990.

ROMÃO-JÚNIOR, J. Doença renal crônica: definição, epidemiologia e classificação. J Bras Nefrol, v.26, n.1, p. 1-3, 2004.

ROOYAKKERS, T. M. et al. Ferric saccharate induces oxygen radical stress and endothelial dysfunction in vivo. Eur J Clin Invest, n.S1, p.9-16, 2002.

SCIGALLA, P. et al. Therapy of renal anemia with recombinant human erythropoietin in children with endstage renal disease. Contrib Nephrol, v.76, p.227-241, 1989.

SESSO, R. C. C. et al. Censo Brasileiro de Diálise, 2009. J Bras Nefrol, v.32, n.4, p.380-384, 2010.

SOCIEDADE BRASILEIRA DE NEFROLOGIA. Senso de diálise. SBN. [S. 1.]. 2011.

TARNG, D.; CHEN, T.; HUANG, T. Iron metobolism indices for early prediction of the response and resistence to erythropoietin therapy in maintenance hemodialysis patients. Am J Nephrol, v.15, p.230-237, 1995. 
TEEHAN, B. et al. Hematologic and physiologic studies during correction of anemia with recombinant human erythropoietin in predialysis patients. Kidney Int, v.34, p.525-528, 1989.

WHO. Iron deficiency anaemia, assessment, prevention and control: a guide for programme managers. Geneva: United Nations Children's Fund; United Nations University; World Health Organization, 2001.

WIZEMANN, V.; SCHÄFER, R.; KRAMER, W. Followup of cardiac changes induced by anemia compensation in normotensive hemodialysis patients with left-ventricular hypertrophy. Nephron, v.64, p.202-206, 1993.

WOLCOTT, D. L. et al. Recombinant human erythropoietin treatment may improve quality of life and cognitive function in chronic hemodialysis patients. Am J Kidney Dis, v.14, p.478-485, 1989. 